\title{
Analisis Faktor Spesifik Bank Terhadap Non Performing Loan Pada Bank Umum Konvensional Yang Terdaftar Di Bursa Efek Indonesia
}

\author{
Meily Juliani $^{1^{*}}$ \\ Universitas Internasional Batam \\ Email: meily.juliani@uib.ac.id \\ *Penulis korespondensi
Diajukan
: 27 November 2021
Disetujui
: 4 Desember 2021
Dipublikasi
: 1 Januari 2022

\begin{abstract}
The purpose of this research is to analyze the effect of bank specific factors on nonperforming loan on public conventional banks. The dependent variable studied was the nonperforming loan and independent variables examined were capital adequacy ratio, bank size, loan to deposit ratio, net interest margin, return on equity, operating expenses to operating income, and earning per share. The secondary data obtained from the annual reports submitted in the IDX. Sample consist of 32 public conventional banks listed in IDX in the period of 2012-2017. The result of this study indicate that bank size and net interest margin has a positive and significant impact on non-performing loan. While return on equity showed a negative and significant impact on non-performing loan. The result of this study also showed that capital adequacy ratio, loan to deposit ratio, operating expenses to operating income and earning per share did not have any significant impact on non-performing loan.
\end{abstract}

Keywords: non-performing loan; conventional bank; bank specific factors; capital adequacy ratio; loan to deposit ratio

\section{PENDAHULUAN}

Perbankan merupakan tumpuan ekonomi negara karena berfungsi sebagai penghubung antara pemodal dengan pengguna dana. Pelayanan yang diberikan oleh Bank melalui kegiatan pembiayaan berfungsi untuk memperlancar sistem pembayaran bagi segala bidang perekonomian melalui kegiatan kredit dan jasa lainnya. Keuntungan sebuah bank bergantung kepada jumlah kredit yang disalurkan, pengelolaan kredit yang tidak baik akan berdampak pada kerugian bank tersebut. Akan tetapi dengan adanya penyaluran kredit kepada masyarakat, bank juga harus mempertimbangkan risiko kredit yang timbul dari adanya kredit bermasalah.

Kegagalan dalam dunia perbankan banyak terjadi di seluruh dunia dan sebagian besar kegagalan perbankan atau krisis perbankan disebabkan oleh kredit bermasalah (Brownbridge, 1998). Menurut Waweru \& Kalani (2009) bank dan lembaga keuangan menghadapi berbagai risiko yang berhubungan dengan risiko pasar dan operasional, sedangkan masalah lainnya berkaitan dengan likuiditas dan peraturan hukum. Namun, kredit bermasalah merupakan risiko terbesar bagi bank karena merupakan sumber pendapatan dan keuntungan bank.

Saat ini penghasilan utama sebagian bank di Indonesia bertumpu pada penyaluran kredit. Sehingga hal tersebut menyebabkan bank di Indonesia lebih rentan terhadap risiko kredit bermasalah. Risiko kredit merupakan indikator kinerja perbankan yang tercermin 
dengan rasio Non Performing Loan (NPL). Bank dengan jumlah NPL yang tinggi dianggap kurang mampu dalam mengelola kreditnya dengan baik (Fajar \& Umanto, 2017). Menurut Alexandri \& Santoso (2015) NPL digunakan untuk menilai kinerja yang berfungsi sebagai lembaga perantara. Tingginya tingkat NPL menunjukkan bahwa rendahnya tingkat kesehatan bank dikarenakan banyaknya kredit bermasalah.

NPL telah menjadi topik pembahasan di Indonesia semenjak terjadinya krisis moneter di tahun 1998. Krisis yang terjadi pada saat tersebut telah berdampak pada maraknya likuidasi bank di Indonesia dikarenakan mata uang rupiah yang mengalami penurunan sehingga menyebabkan kenaikan tingkat suku bunga yang berdampak pada banyaknya debitur yang tidak sanggup melunasi kewajiban pinjaman dan bunga dalam mata uang dollar Amerika. Hal tersebut terjadi dikarenakan kurang baiknya sistem penyaluran kredit serta minimnya manajemen risiko kredit pada industri perbankan.

Menurut data Otoritas Jasa Keuangan, pada tahun 2014 tingkat NPL industri perbankan sebesar 2,16 \% kemudian meningkat di tahun 2015 menjadi sebesar 2,49\% sedangkan di 2016, kembali meningkat menjadi 2,93\%. Pada tahun 2017, NPL industri perbankan menjadi 2,55\% Berdasarkan data tersebut dapat disimpulkan bahwa persentase NPL mengalami peningkatan. Peningkatan rasio NPL di Indonesia disebabkan oleh kondisi perekonomian yang sedang lesu sehingga berdampak kepada penurunan kualitas kredit dari sektor industri dan perdagangan.

\section{Teori Too Big To Fail}

\section{KAJIAN LITERATUR}

Teori too big to fail diungkapkan oleh Stern \& Feldman (2004) yang menjelaskan mengenai kebijakan pemerintah dalam melindungi institusi keuangan yang berskala besar dari semua atau sebagian kerugian yang seharusnya ditanggung. Pandangan TBTF atau disebut dengan istilah terlalu besar untuk gagal menyatakan bahwa kegagalan sebuah bank besar akan menghasilkan risiko yang berdampak besar terhadap sistem keuangan dan kemungkinan akan berdampak terhadap tatanan ekonomi dan sosial negara tersebut. Berdasarkan pandangan tersebut pemuat kebijakan di beberapa negara maju dan berkembang merespons dengan melindungi kreditur bank dari semua atau sebagian kerugian yang dihadapi.

\section{Non Performing Loan (NPL)}

UU No. 10 Tahun 1998 menjelaskan bahwa kredit merupakan kegiatan penyediaan dana berdasarkan perjanjian atau kesepakatan peminjaman antara bank tersebut dengan pihak lain yang mengharuskan pihak yang meminjam untuk melunasi hutangnya dalam jangka waktu yang ditentukan disertai dengan pemberian bunga. Akan tetapi dalam UU No.7 Tahun 1992 menjelaskan bahwa dalam penyaluran kredit, bank umum diwajibkan memiliki kepercayaan terhadap kemampuan debitur dalam pelunasan hutang sesuai dengan perjanjian. Berdasarkan UU tersebut dapat disimpulkan bahwa untuk menjaga tingkat likuiditas dan solvabilitasnya, bank harus lebih cermat dalam hal penyaluran kredit terhadap nasabahnya. Menurut SAK No. 31 revisi Tahun 2000 kredit bermasalah atau disebut sebagai Nonperforming loan adalah pembayaran kredit yang cicilan pokok atau bunganya telah melewati 90 hari atau lebih setelah jatuh tempo atau kredit yang ketepatan waktu pembayarannya sangat diragukan.

\section{Rasio Kecukupan Modal Terhadap NPL}

Menurut Rahman et al., (2017) rasio kecukupan modal mengukur risiko yang dapat diambil oleh bank. Menurut Alexandri \& Santoso (2015) modal mempunyai fungsi sebagai 
penyangga untuk menanggung kerugian yang muncul dari berbagai risiko. Semakin besar rasio kecukupan modal sebuah bank, maka semakin meningkat pula kapabilitas bank dalam menanggung resiko dari setiap kredit atau aktiva produktif bank yang berisiko. Jika nilai rasio kecukupan modal tinggi maka bank mampu dalam pembiayaan kegiatan operasionalnya dan memberikan andil yang besar bagi profitabilitas, sehingga dapat menurunkan tingkat NPL. Hasil ini sejalan dengan penelitian Klein (2013), Shingjergji \& Aleksander (2013) Rahman et al., (2016) yang menemukan bahwa rasio kecukupan modal (CAR) berpengaruh signifikan negatif terhadap NPL. Sedangkan Vatansever \& Hepşen (2013) dan (Alexandri \& Santoso (2015) menemukan adanya hubungan signifikan positif. Akan tetapi Jameel (2014), Sari et al., (2015), El-Maude et al., (2017) dan Malimi (2017) tidak menemukan adanya pengaruh signifikan antara rasio kecukupan modal terhadap NPL.

$\mathrm{H}_{1}$ : Rasio kecukupan modal berpengaruh signifikan negatif terhadap NPL

\section{Ukuran Bank Terhadap NPL}

Menurut Louzis et al., (2012) bank yang mempunyai ukuran yang lebih besar cenderung terdorong untuk mengambil risiko yang berlebihan dengan meningkatkan leverage-nya dibawah asumsi too big to fail dan hal tersebut akan menyebabkan tingginya nilai NPL. Hal ini terjadi karena keyakinan bahwa pemerintah dapat membantu bank besar yang mengalami risiko agar tidak berdampak pada perekonomian negara.

Ketika bank dengan ukuran yang lebih besar mengalami kegagalan bisnis maka dapat memberikan pengaruh besar terhadap perekonomian. Penyaluran kredit merupakan kegiatan utama bank, maka semakin tinggi risiko kegagalan bisnis yang akan terjadi sehingga bank akan menanggung risiko kredit yang semakin besar. Hal ini akan menyebabkan kemungkinan terjadinya peningkatan NPL.

Hasil ini sejalan dengan Abid et al., (2014),Chaibi \& Ftiti (2015), Gabeshi (2017) dan El-Maude et al., (2017) yang menemukan adanya hubungan positif antara ukuran bank dengan NPL. Sedangkan penelitian ini bertentangan dengan penelitian Swamy (2012), Ekanayake \& Azeez (2015), Polodoo et al., (2015), Alexandri \& Santoso (2015), serta Sari et al., (2015) yang menemukan adanya hubungan signifikan negatif antara ukuran bank dengan NPL. Sedangkan Fajar \& Umanto (2017) tidak menemukan adanya hubungan adanya hubungan signifikan antara ukuran bank dengan NPL.

\section{$\mathrm{H}_{2}$ : Ukuran bank berpengaruh signifikan positif terhadap NPL}

\section{Loan To Deposit Ratio Terhadap NPL}

Rasio LDR merupakan tolak ukur besar kecil jumlah penyaluran kredit oleh bank, maka rasio LDR yang semakin tinggi mencerminkan semakin besar jumlah kredit yang didistribusikan. Semakin besar penyaluran jumlah kredit oleh bank, maka risiko terjadinya kredit bermasalah akan lebih besar. Hal ini dapat terjadi karena terdapat penetapan batas waktu atas pengembalian pinjaman sehingga kredit tersebut akan menjadi bermasalah.

Penelitian ini sejalan dengan penelitian Gabeshi (2017) dan El-Maude et al., (2017) yang menemukan adanya hubungan signifikan positif antara LDR terhadap NPL. Hasil ini bertentangan dengan penelitian Diyanti \& Widyarti (2012) yang menemukan adanya hubungan signifikan negatif antara LDR terhadap NPL. Sedangkan Makri et al., (2014) dan Sari et al., (2015) tidak menemukan adanya hubungan LDR terhadap NPL.

\section{$\mathrm{H}_{3} \quad$ : LDR berpengaruh signifikan positif terhadap NPL}




\section{Net Interest Margin Terhadap NPL}

Menurut Barus \& Erick (2016) pendapatan bunga bank akan mengalami peningkatan apabila kredit yang tersalurkan mengalami peningkatan. Semakin besar penyaluran kredit oleh bank maka semakin besar risiko terjadinya kredit bermasalah, sehingga hal tersebut akan mempengaruhi NPL. Tingginya proporsi kredit bermasalah dapat menyebabkan meningkatnya NIM untuk mengkompensasi kemungkinan adanya resiko (Rahman et al., 2016).

Hasil penelitian ini sejalan dengan penelitian Shingjergji \& Aleksander (2013) dan Malimi (2017). Akan tetapi bertentangan dengan penelitian Sari et al., (2015) dan Rahman et al., (2017) yang tidak menemukan adanya hubungan antara NIM terhadap NPL.

\section{$\mathrm{H}_{4} \quad$ : NIM berpengaruh signifikan positif terhadap NPL}

\section{Return on Equity Terhadap NPL}

Menurut Louzis et al., (2012) peningkatan kredit bermasalah akan menyebabkan bank mengalami penurunan tingkat ROE. Bank akan mengalami kesulitan dalam memulihkan pinjamannya dan akibatnya akan menyebabkan penurunan kinerja bank yang pada akhirnya akan berpengaruh pada tingkat ROE yang lebih rendah. Hal ini menyebabkan ROE berpengaruh signifikan negatif terhadap NPL. Hal ini sejalan dengan penelitian Louzis et al., (2012), Klein (2013), Shingjergji \& Aleksander (2013), Abid et al., (2014), Makri et al., (2014), Chaibi \& Ftiti (2015), Gabeshi (2017) dan Sari et al., (2015). Akan tetapi bertentangan dengan penelitian Fajar \& Umanto (2017) yang menemukan adanya hubungan positif antara Return on Equity (ROE) terhadap NPL.

\section{$\mathrm{H}_{5} \quad$ : ROE berpengaruh signifikan negatif terhadap NPL}

\section{Beban Operasional Terhadap Pendapatan Operasional Terhadap NPL}

Menurut Dendawijaya (2015) biaya dan pendapatan bank sebagian besar didapat dari biaya bunga dan hasil bunga dikarenakan aktivitas utama bank meliputi penghimpunan dan penyaluran dana masyarakat. BOPO merupakan sebuah rasio yang mencerminkan tingkat efisiensi sebuah bank berdasarkan biaya, harga, dan kompleksitas produk.

Berdasarkan SE BI No. 17/10/PBI/2015 yang menetapkan nilai ideal rasio BOPO yaitu antara 50\% - 75\% serta harus memiliki BOPO maksimal $85 \%$. Bank yang memiliki BOPO melebihi dari ketentuan BI akan digolongkan kurang sehat dan inefisien. BOPO berkontribusi sangat besar terhadap perbankan karena mencerminkan kemampuan sebuah bank untuk mengelola asetnya untuk menghasilkan laba. BOPO juga mencerminkan kualitas manajemen bank dalam hal efisiensi. Semakin rendah biaya operasional bank, maka bank tersebut akan semakin efisien sehingga dapat meningkatkan kesehatan dan profitabilitasnya. Tingkat kesehatan bank yang tinggi dapat meminimalkan risiko kredit (Sari et al., 2015).

Semakin meningkatnya kredit bermasalah, maka akan menghambat terbentuknya pendapatan bunga yang akan diterima oleh bank serta mempengaruhi pembentukan beban Penyisihan Pencadangan Piutang Aktiva Produktif (PPAP) yang akan meningkat sehingga hal tersebut akan mengurangi pendapatan yang diterima oleh bank. Oleh karena itu, BOPO berpengaruh signifikan positif terhadap NPL. Hipotesis ini sejalan dengan penelitian Louzis et al., (2012), Ekanayake \& Azeez, (2015), Fajar \& Umanto, (2017), dan Sari et al., (2015). Akan tetapi hasil tersebut bertentangan dengan penelitian Vatansever \& Hepşen (2013) yang menemukan hubungan signifikan negatif antara BOPO dan NPL. Sedangkan Chaibi \& Ftiti (2015) tidak menemukan adanya pengaruh signifikan antara BOPO terhadap NPL.

\section{$\mathrm{H}_{6} \quad$ : BOPO berpengaruh signifikan positif terhadap NPL}




\section{Laba Per Lembar Saham Terhadap NPL}

Khan \& Ahmad (2017) menyatakan bahwa para pemegang saham di perusahaan sangat memperhatikan rasio laba per lembar saham karena dapat memberikan gambaran keseluruhan terhadap kinerja bank. Semakin tinggi rasio laba per lembar saham maka menunjukkan bahwa bank menghasilkan pendapatan yang tinggi dan akan menurunkan tingkat NPL.

Menurut Cheng et al., (2016) semakin tinggi laba per lembar saham sebuah perusahaan maka semakin tinggi pula tingkat profitabilitas per unit modal perusahaan tersebut. Sehingga rasio EPS yang tinggi akan menunjukkan bahwa bank mempunyai kemampuan yang lebih baik dari bank lain. Rasio NPL yang tinggi mempengaruhi profitabilitas bank sehingga menyebabkan menurunnya tingkat pendapatan.

Penelitian ini sejalan dengan penelitian Khan \& Ahmad (2017) yang menemukan adanya hubungan signifikan negatif antara laba per lembar saham dan NPL. Akan tetapi hasil tersebut tidak sejalan dengan penelitian Cheng et al., (2016) yang menemukan adanya hubungan signifikan positif antara laba per lembar saham dan NPL.

$\mathrm{H}_{7} \quad$ : Laba per lembar saham berpengaruh signifikan negatif terhadap NPL

\section{Rancangan Penelitian}

\section{METODE}

Penelitian ini merupakan penelitian kausal komparatif yang menganalisis hubungan rasio kecukupan modal, ukuran bank, LDR, NIM, ROE, BOPO, serta laba per lembar saham terhadap non performing loan. Penelitian bersifat kuantitatif dan merupakan penelitian dasar. Penelitian menggunakan metode analisis data regresi berganda. Metode tersebut digunakan untuk melihat pengaruh dua atau lebih variabel independen terhadap variabel dependen (Indriantoro \& Supomo, 2016). Program yang digunakan untuk pengujian data outlier yaitu program SPSS versi 22 serta regresi panel menggunakan Eviews versi 8.

Tabel 1. Definisi Operasional Variabel

\begin{tabular}{|c|c|c|}
\hline Variabel & Pengukuran & Sumber \\
\hline Non Performing Loan & $\frac{\text { Total Kredit Bermasalah }}{\text { Total Kredit }}$ & SEBI No.13/30/DPNP/2011 \\
\hline Rasio Kecukupan Modal & $\frac{\text { Modal }}{\text { Aset Tertimbang Menurut Risiko }}$ & PBI No. 3/21/PBI/2001 \\
\hline Ukuran Bank & Log Total Aset & (Gabeshi, 2017) \\
\hline Loan To Deposit Ratio & $\frac{\text { Total Kredit }}{\text { Dana Pihak Ketiga }}$ & PBI No. 17/11/PBI/2015 \\
\hline Net Interest Margin & $\frac{\text { Pendapatan Bunga Bersih }}{\text { Aset Produktif }}$ & SEBI No.13/30/DPNP/2011 \\
\hline Return On Equity & $\frac{\text { Laba Setelah Pajak }}{\text { Rata-Rata Equity }}$ & SEBI No.6/23/DPNP/2004 \\
\hline $\begin{array}{ll}\text { Beban } & \text { Operasional } \\
\text { Terhadap } & \text { Pendapatan } \\
\text { Operasional } & \end{array}$ & $\frac{\text { Beban Operasional }}{\text { Pendapatan Operasional }}$ & $\begin{array}{l}\text { SEBI } \\
\text { No.15/29/DKBU/2013 }\end{array}$ \\
\hline Laba Per Lembar Saham & $\frac{\text { Laba bersih }}{\text { Total saham beredar }}$ & (Khan \& Ahmad, 2017) \\
\hline
\end{tabular}




\section{Statistik Deskriptif}

\section{HASIL}

Data penelitian mengambil sampel data bank umum konvensional yang terdaftar di Bursa Efek Indonesia. Data sekunder penelitian menggunakan laporan keuangan tahunan pada 2012-2017, jumlah bank umum yang diteliti adalah 32 perusahaan dengan total 192 data. Terdapat 14 data outlier sehingga data observasi menjadi 178 data.

Tabel 2. Statistik Deskriptif

\begin{tabular}{|l|l|l|l|l|l|}
\hline & N & Minimum & Maksimum & Rata-Rata & Standar Deviasi \\
\hline NPL & 192 & 0 & 0.15820 & 0.0254224 & 0,21585 \\
\hline CAR & 192 & 0.10090 & 0,87490 & 0,1944307 & 0,07951 \\
\hline $\begin{array}{l}\text { SIZE (Dalam Jutaan } \\
\text { Rupiah) }\end{array}$ & 192 & 1.048 .147 & 1.126 .248 .442 & 139.547 .942 & 235.787 .233 \\
\hline LDR & 192 & 0,42020 & 1,13300 & 0,8360115 & 0,13984 \\
\hline NIM & 192 & 0,00240 & 0,13100 & 0,0519250 & 0,02104 \\
\hline ROE & 192 & $-1,42480$ & 0,38660 & 0,0823026 & 0,18593 \\
\hline BOPO & 192 & 0,47860 & 2,35200 & 0,8674385 & 0,21588 \\
\hline EPS & 192 & -485 & 320.085 & 1809,61 & 23091,1 \\
\hline
\end{tabular}

Sumber: Data Sekunder diolah (2018)

Hasil menyajikan bahwa NPL memiliki angka minimum sebesar 0\% dan angka maksimum sebesar $15,82 \%$ yang berarti tingkat NPL pada perusahaan yang terdaftar di BEI yang paling terkecil adalah $0 \%$ dan paling terbesar adalah 15,82\%. Angka rata-rata NPL menjelaskan bahwa rata-rata perusahaan perbankan konvensional di BEI mempunyai tingkat NPL sebesar 2,54\%. Menurut peraturan BI no.17/11/PBI/2015 yang mewajibkan bank umum di Indonesia memiliki ukuran tingkat rasio NPL dibawah 5\% sehingga kesimpulan yang dapat diambil adalah terdapat beberapa bank umum yang masih memiliki rasio NPL yang cukup tinggi serta belum memenuhi persyaratan tersebut.

Variabel rasio kecukupan modal memiliki angka minimum sebesar 10,09\% dan angka maksimum $87,49 \%$ serta nilai rata-rata rasio kecukupan modal di perusahaan perbankan konvensional di BEI adalah sebesar 19,44\%. Dilihat berdasarkan dari ketentuan Bank Indonesia terkait minimum penyediaan modal di Indonesia yaitu 8\%, maka rasio kecukupan modal di Indonesia sudah memenuhi ketentuan yang berlaku.

Variabel ukuran bank memiliki angka minimum sebesar 1 triliyun rupiah dan angka maksimum 1.126 triliyun rupiah dan nilai rata-rata menunjukkan bahwa perusahaan perbankan konvensional di BEI mempunyai harga pasar sebesar 139 triliyun rupiah. Hasil menyimpulkan bahwa bank umum di Indonesia memiliki pertumbuhan aset yang pesat karena rata-rata aset yang dimiliki berada diatas angka 100 triliyun rupiah.

Variabel LDR memiliki angka minimum sebesar 42,02\% dan angka maksimum $113,3 \%$ serta nilai rata-rata rasio LDR di perusahaan perbankan konvensional di BEI mempunyai rata-rata sebesar $83,60 \%$. Dapat disimpulkan bahwa tingkat penyaluran kredit di bank umum masih tinggi karena perbandingan antara jumlah kredit dan dana pihak ketiga berada diatas angka $40 \%$.

Variabel NIM memiliki angka minimum sebesar 0,24\% dan angka maksimum 13,1\% serta nilai rata-rata rasio NIM di perusahaan perbankan konvensional di BEI mempunyai ratarata marjin bunga bersih sebesar 5,19\%. Berdasarkan tabel diatas dapat disimpulkan bahwa tingkat pendapatan bunga di bank umum masih relatif stabil. 
Variabel ROE memiliki angka minimum sebesar $-142,48 \%$ dan angka maksimum $38,66 \%$ serta nilai rata-rata ROE di perusahaan perbankan konvensional di BEI mempunyai tingkat pengembalian ekuitas rata-rata sebesar 8,23\%. Hasil menjelaskan bahwa di Indonesia kinerja bank umum masih relatif rendah.

Variabel BOPO memiliki angka minimum sebesar 47,86\% dan angka maksimum $235,2 \%$ serta nilai rata-rata BOPO di perusahaan perbankan konvensional di BEI mempunyai rata-rata sebesar $86,74 \%$. Berdasarkan ketentuan Bank Indonesia yang menyatakan bahwa rasio BOPO yang ideal adalah berada diantara 50\% - 75\% dan nilai maksimum $85 \%$, maka dapat ditarik kesimpulan bahwa di Indonesia bank umum belum efisien karena rasio BOPOnya yang sangat besar.

Variabel laba per lembar saham memiliki nilai minimum sebesar -485 dan nilai maksimum 320.085 serta nilai rata-rata laba per saham adalah sebesar 1.809 jika dihitung dari laba bersih terhadap total saham beredar. Hasil menjelaskan tingkat pengembalian laba pada bank umum di Indonesia masih relatif stabil.

\section{Pemilihan Model Terbaik}

Uji Chow

Tabel 3. Hasil Uji Chow

\begin{tabular}{|c|c|c|c|}
\hline Variabel Dependen & Effect Test & Prob. & Kesimpulan \\
\hline NPL & Cross Section Chi-Square & 0,0000 & Fixed Effect Model \\
\hline
\end{tabular}

Sumber: Data yang diolah (2018)

Hasil uji chow pada tabel 3 menunjukkan nilai NPL dari data yang diuji adalah 0,0000 sehingga model yang digunakan untuk menguji variabel dependen tersebut adalah fixed effect model. Dengan hasil demikian, maka pengujian dilanjutkan menggunakan uji hausman.

\section{Uji Hausman}

Tabel 4. Hasil Uji Hausman

\begin{tabular}{|l|l|l|l|}
\hline Variabel Dependen & Effect Test & Prob. & Kesimpulan \\
\hline NPL & Cross Section Random & 0,0049 & Fixed Effect Model \\
\hline
\end{tabular}

Sumber: Data yang diolah (2018)

Hasil uji hausman menunjukkan bahwa nilai probabilitas cross section random 0,0049 lebih kecil dari 0,05 sehingga model regresi panel yang paling tepat digunakan adalah fixed effect model.

\section{Hasil Uji F}

Tabel 5. Hasil Uji F

\begin{tabular}{|c|c|c|c|}
\hline Variabel Dependen & Effect Test & Prob. & Kesimpulan \\
\hline NPL & Cross Section Fixed & 0,000000 & Signifikan \\
\hline
\end{tabular}

Sumber: Data yang diolah (2018)

Hasil yang disajikan dalam Tabel 5 menunjukkan hasil sebesar 0,000000. Model regresi tersebut menunjukkan angka di bawah tingkat probabilitas 0,05. Sehingga model dapat digunakan untuk menjelaskan nilai NPL.

\section{Hasil Uji t}

Tabel 6. Hasil Uji t

\begin{tabular}{|l|l|l|l|l|l|}
\hline Variabel & Koefisien & t-statistic & Prob & Kesimpulan & Hipotesis \\
\hline
\end{tabular}


Owner: Riset \& Jurnal Akuntansi

e-ISSN : 2548-9224 |p-ISSN : 2548-7507

Volume 6 Nomor 1, Januari 2022

Owner

DOI : https://doi.org/10.33395/owner.v6i1.569

\begin{tabular}{|l|l|l|l|l|l|}
\hline (Constant $)$ & $-0,185206$ & $-1,747875$ & 0,0827 & & \\
\hline CAR & $-0,030116$ & $-1,122998$ & 0,2634 & Non-Sig & $\begin{array}{l}\text { Tidak } \\
\text { Terbukti }\end{array}$ \\
\hline SIZE & 0,006779 & 2,067804 & 0,0405 & Sig+ & Terbukti \\
\hline LDR & $-0,008288$ & $-0,558018$ & 0,5777 & Non-Sig & $\begin{array}{l}\text { Tidak } \\
\text { Terbukti }\end{array}$ \\
\hline NIM & 0,461041 & 3,245342 & 0,0015 & Sig+ & Terbukti \\
\hline ROE & $-0,134311$ & $-6,030714$ & 0,0000 & Sig- & Terbukti \\
\hline BOPO & 0,001314 & 0,089044 & 0,9292 & Non-Sig & $\begin{array}{l}\text { Tidak } \\
\text { Terbukti }\end{array}$ \\
\hline EPS & $-7,93 E-06$ & $-0,844176$ & 0,4000 & Non-Sig & $\begin{array}{l}\text { Tidak } \\
\text { Terbukti }\end{array}$ \\
\hline
\end{tabular}

Sumber: Data sekunder diolah (2018)

Hasil pengujian variabel rasio kecukupan modal pada tabel 6 menunjukkan bahwa nilai probabilitas sebesar 0,2634 nilai tersebut lebih besar dari pada nilai probabilitas yaitu 0,05 . Sehingga dapat disimpulkan bahwa rasio kecukupan modal tidak berpengaruh signifikan terhadap NPL. Hasil penelitian ini menolak hipotesis $1\left(\mathrm{H}_{1}\right)$.

Hasil pengujian terhadap variabel ukuran bank menunjukkan koefisien regresi sebesar 0,006779 dan nilai probabilitas sebesar 0,0405 nilai tersebut lebih kecil dari pada nilai probabilitas yaitu 0,05. Oleh karena itu, dapat disimpulkan bahwa ukuran bank berpengaruh signifikan positif terhadap NPL. Hasil penelitian ini menerima Hipotesis $2\left(\mathrm{H}_{2}\right)$.

Hasil pengujian variabel LDR menunjukkan nilai probabilitas sebesar 0,5777 dimana nilai tersebut lebih besar dari pada nilai probabilitas yaitu 0,05 . Sehingga dapat disimpulkan bahwa LDR tidak berpengaruh signifikan terhadap NPL. Hasil penelitian ini menolak hipotesis $3\left(\mathrm{H}_{3}\right)$.

Hasil pengujian terhadap variabel NIM menunjukkan nilai koefisien regresi sebesar 0,461041 dan nilai probabilitas sebesar 0,0015 dimana nilai tersebut lebih kecil dari pada nilai probabilitas yaitu 0,05 . Oleh karena itu, dapat disimpulkan bahwa NIM mempunyai pengaruh signifikan positif terhadap NPL. Hasil penelitian ini menerima hipotesis $4\left(\mathrm{H}_{4}\right)$.

Hasil pengujian terhadap variabel ROE menunjukkan koefisien regresi sebesar 0,134311 dengan nilai probabilitas 0,0000 dimana nilai tersebut lebih kecil dari pada nilai probabilitas yaitu 0,05. Oleh karena itu, dapat disimpulkan bahwa ROE berpengaruh signifikan negatif terhadap NPL. Hasil penelitian ini menerima hipotesis $5\left(\mathrm{H}_{5}\right)$.

Hasil pengujian terhadap variabel BOPO menunjukkan nilai probabilitas sebesar 0,9292 dimana nilai tersebut lebih besar dari nilai probabilitas yaitu 0,05 . Sehingga dapat disimpulkan bahwa BOPO tidak berpengaruh signifikan terhadap NPL. Hasil penelitian ini menolak hipotesis $6\left(\mathrm{H}_{6}\right)$.

Hasil pengujian terhadap variabel laba per lembar saham menunjukkan nilai probabilitas sebesar 0,4000 dimana nilai tersebut lebih besar dari nilai probabilitas yaitu 0,05. Sehingga dapat disimpulkan bahwa laba per lembar saham tidak berpengaruh terhadap NPL. Hasil penelitian ini menolak hipotesis $7\left(\mathrm{H}_{7}\right)$.

\section{Hasil Goodness of Fit Model}

Tabel 7. Hasil Uji Goodness of Fit Model

\begin{tabular}{|c|c|c|}
\hline Model Regresi & Adjusted $\boldsymbol{R}^{2}$ & Std. Error of Regression \\
\hline Non-Performing Loan & 0,623475 & 0,009675 \\
\hline
\end{tabular}

Sumber: Data yang diolah (2018) 
Model regresi NPL menunjukkan angka adjusted $R^{2}$ sebesar $62,34 \%$. Nilai tersebut menunjukkan bahwa variabel independen yang digunakan dalam model regresi NPL dapat menjelaskan variasi variabel dependen NPL sebesar $62,34 \%$.

\section{Rasio Kecukupan Modal Terhadap NPL}

\section{PEMBAHASAN}

Hasil pengujian menunjukkan bahwa rasio kecukupan modal tidak berpengaruh signifikan terhadap NPL. Hal ini terjadi karena semakin besar nilai rasio kecukupan modal yang dimiliki oleh bank maka kapasitas sebuah bank dalam menanggung risiko kredit atau aktiva produktif bank akan menjadi lebih baik. Akan tetapi terdapat probabilitas bahwa peningkatan modal tersebut akan digunakan oleh pihak manajemen untuk investasi lain ataupun untuk mendanai kegiatan operasional dan bukan digunakan untuk meningkatkan alokasi dana kredit atau untuk menutup risiko kredit yang telah terjadi. Hasil ini didukung oleh Jameel (2014), El-Maude et al., (2017), Sari et al., (2015), dan Malimi (2017).

\section{Ukuran Bank Terhadap NPL}

Hasil pengujian menunjukkan bahwa ukuran bank berpengaruh signifikan positif terhadap NPL. Menurut Louzis et al., (2012) bank yang berukuran lebih besar akan cenderung termotivasi untuk mengambil risiko yang lebih besar dengan meningkatkan leverage-nya dibawah pandangan too big to fail dan hal tersebut akan menyebabkan tingginya nilai NPL. Hal ini disebabkan karena pemerintah dapat membantu bank besar tersebut jika risiko tersebut terjadi agar tidak berdampak pada perekonomian negara. Hasil penelitian ini didukung oleh Abid et al., (2014), Gabeshi (2017) dan El-Maude et al., (2017).

\section{Loan To Deposit Ratio Terhadap NPL}

Hasil pengujian menunjukkan bahwa LDR tidak berpengaruh signifikan terhadap NPL. Hal ini dapat terjadi karena bank yang mempunyai tingkat NPL yang tinggi kemungkinan besar akan menghentikan penyaluran kredit nya untuk sementara waktu dan lebih fokus dalam penanganan kredit bermasalah terlebih dahulu. Hasil penelitian ini didukung oleh Makri et al., (2014) dan Sari et al., (2015).

\section{Net Interest Margin Terhadap NPL}

Hasil pengujian menunjukkan bahwa NIM berpengaruh signifikan positif terhadap NPL. Semakin tinggi rasio NIM menunjukkan bahwa semakin besar pendapatan yang diperoleh oleh sebuah bank dari penyaluran kreditnya, maka semakin banyak kredit yang disalurkan maka semakin besar pula potensi terjadinya kredit bermasalah. Hasil penelitian ini sejalan dengan Shingjergji \& Aleksander (2013) dan Malimi (2017).

\section{Return on Equity Terhadap NPL}

Berdasarkan hasil pengujian menunjukkan bahwa ROE berpengaruh signifikan negatif terhadap NPL. Ketika bank mengalami peningkatan kredit bermasalah maka bank tersebut akan mengalami kesulitan dalam memulihkan pinjamannya sehingga akan berdampak pada penurunan kinerja bank yang pada akhirnya akan berdampak pada penurunan tingkat ROE. Hasil penelitian ini didukung oleh Louzis et al., (2012), Klein (2013), Shingjergji \& Aleksander (2013), Abid et al., (2014), Sari et al., (2015) dan (Gabeshi, 2017). 


\section{BOPO Terhadap NPL}

Hasil pengujian menunjukkan bahwa BOPO tidak berpengaruh signifikan terhadap NPL. Pendapatan operasional bank tidak hanya berasal dari pendapatan bunga kredit yang disalurkan saja, namun didapatkan dari pendapatan aktiva produktif lainnya seperti fee based income yaitu pendapatan yang berasal dari biaya administrasi tabungan, provisi, inkaso, dan lain-lain sehingga nilai BOPO tidak mempengaruhi NPL. Hasil penelitian ini didukung oleh Chaibi \& Ftiti (2015).

\section{Laba Per Lembar Saham Terhadap NPL}

Hasil pengujian menunjukkan bahwa laba per lembar saham tidak berpengaruh terhadap NPL. Hal ini dapat terjadi dikarenakan adanya campur tangan dari pemerintah terhadap sektor perbankan yang membantu bank yang mempunyai kinerja buruk untuk mempertahankan stabilitas di pasar finansial sehingga perubahan laba per lembar saham tidak berpengaruh terhadap NPL. Di Indonesia terdapat kebijakan dalam bentuk asuransi simpanan yang dikelola oleh Lembaga Penjamin Simpanan yang dibentuk berdasarkan UU No 7 Tahun 2009. LPS merupakan sebuah lembaga yang bermanfaat untuk menjamin simpanan nasabah serta turut berpartisipasi dalam memelihara kestabilan sistem perbankan. Sehingga, keyakinan bank-bank sangat besar untuk mendapatkan bantuan dana karena apabila bank tersebut gagal akan menimbulkan efek domino terhadap institusi lainnya. Penelitian ini tidak sejalan dengan penelitian Khan \& Ahmad (2017).

\section{KESIMPULAN}

Berdasarkan hasil analisa terhadap pengaruh faktor spesifik bank yaitu rasio kecukupan modal, ukuran bank, LDR, NIM, ROE, BOPO, dan laba per lembar saham terhadap NPL pada bank umum konvensional pada tahun 2012-2017 dapat diambil kesimpulan bahwa ukuran bank, net interest margin (NIM), serta return on equity (ROE) mempengaruhi NPL. Penelitian ini juga menunjukkan bahwa rasio kecukupan modal, LDR, BOPO dan laba per lembar saham tidak berpengaruh terhadap NPL.

\section{REFERENSI}

Abid, L., Ouertani, M. N., \& Zouari-Ghorbel, S. (2014). Macroeconomic and Bank-specific Determinants of Household's Non-performing Loans in Tunisia: A Dynamic Panel Data. Procedia Economics and Finance, 13, 58-68. https://doi.org/10.1016/s22125671(14)00430-4

Alexandri, M. B., \& Santoso, T. I. (2015). Non Performing Loan: Impact of Internal and External Factor (Evidence in Indonesia) (Vol. 4). www.ijhssi.org

Bank Indonesia. (2001). Peraturan Bank Indonesia No 3/21/PBI/2001 tentang Kewajiban Penyediaan Modal Minimum Bank Umum. www.bi.go.id

Bank Indonesia. (2004). Surat Edaran Bank Indonesia No 6/23/DPNP/2004 Perihal Sistem Penilaian Tingkat Kesehatan Bank. www.bi.go.id

Bank Indonesia. (2011). Surat Edaran Bank Indonesia No 13/30/DPNP/2011 Perihal Penilaian Tingkat Kesehatan Bank Umum. www.bi.go.id

Bank Indonesia. (2011). Lampiran Surat Edaran (SE) Bank Indonesia No 15/29/DKBU/2011. www.bi.go.id 
Bank Indonesia. (2015). Peraturan Bank Indonesia No 17/11/PBI/2015 Tentang Perubahan Atas Peraturan Bank Indonesia No 15/15/PBI/2013 Tentang Giro Wajib Minimum Bank Umum Dalam Rupiah dan Valuta Asing Bagi Bank Umum Konvensional.

Barus, A. C., \& Erick. (2016). Analisis Faktor-Faktor yang Mempengaruhi Non Performing Loan Pada Bank Umum di Indonesia. Jurnal Wira Ekonomi Mikroskil (Vol. 6).

Brownbridge, M. (1998). The Causes Of Financial Distress in Local Banks in Africa and Implications For Prudential Policy. http://www.unicc.org/unctad/en/pressref/prdis.htm*

Chaibi, H., \& Ftiti, Z. (2015). Credit risk determinants: Evidence from a cross-country study. Research in International Business and Finance, 33, 1-16. https://doi.org/10.1016/j.ribaf.2014.06.001

Cheng, M.-C., Lee, C.-C., Nhu, Q., Pham, T., \& Chen, H.-Y. (2016). Factors affect NPL in Taiwan Banking Industry. In Journal of Accounting (Vol. 6, Issue 1).

Dendawijaya, L. (2015). Manajemen Perbankan. Ghalia Indonesia.

Diyanti, A., \& Widyarti, E. T. (2012). Analisis Pengaruh Faktor Internal dan Eksternal Terhadap Terjadinya Non-Performing Loan (Studi Kasus pada Bank Umum Konvensional yang Menyediakan Layanan Kredit Pemilikan Rumah Periode 20082011). Diponegoro Journal Of Management (Vol. 1, Issue 2). http://ejournals1.undip.ac.id/index.php/djom

Ekanayake, E. M. N., \& Azeez A. (2015). Determinants of Non-Performing Loans in Licensed Commercial Banks: Evidence from Sri Lanka. Asian Economic and Financial Review, 5(6), 868-882. https://doi.org/10.18488/journal.aefr/2015.5.6/102.6.868.882

El-Maude, J. G., Abdul-Rahman, A., \& Ibrahim, M. (2017). Determinants of Non-Performing Loans in Nigerias Deposit Money Banks. Archives of Business Research, 5(1). https://doi.org/10.14738/abr.51.2368

Fajar, H., \& Umanto. (2017). The Impact of Macroeconomic and Bank-Specific Factors Toward Non-Performing Loan: Evidence From Indonesian Public Banks. https://doi.org/10.21511/bbs.12(1).2017.08

Gabeshi, K. (2017). The Impact of Macroeconomic and Bank Specific Factors on Albanian Non-Performing Loans Publication Info. Turkey) EJSDR, 2(1), 95-102.

Indriantoro, N., \& Supomo, B. (2016). Metodologi Penelitian Bisnis untuk Akuntansi \& Manajemen: Vol. XVII. BPFE.

Jameel, K. (2014). Crucial Factors of Nonperforming loans Evidence from Pakistani Banking Sector. International Journal of Scientific \& Engineering Research, 5(7). http://www.ijser.org

Khan, I., \& Ahmad, A. (2017). Assessing Banks Internal Factors as Determinants of NonPerforming Loans: Evidence from Pakistani Commercial Banks.

Klein, N. (2013). Non-Performing Loans in CESEE: Determinants and Impact on Macroeconomic Performance. 
Louzis, D. P., Vouldis, A. T., \& Metaxas, V. L. (2012). Macroeconomic and bank-specific determinants of non-performing loans in Greece: A comparative study of mortgage, business and consumer loan portfolios. Journal of Banking and Finance, 36(4), 10121027. https://doi.org/10.1016/j.jbankfin.2011.10.012

Makri, V., Tsagkanos, A., \& Bellas, A. (2014). Determinants of non-performing loans: The case of Eurozone. Panoeconomicus, 61(2), 193-206. https://doi.org/10.2298/PAN1402193M

Malimi, K. (2017). The Influence of Capital Adequacy, Profitability, and Loan Growth on Non-Performing Loans a Case of Tanzanian Banking Sector. International Journal of Economics, Business and Management Studies, 4(1), 38-49. https://doi.org/10.20448/802.41.38.49

Polodoo, V., Seetanah, B., Sannassee, R. V., Seetah, K., \& Padachi, K. (2015). An Econometric Analysis Regarding the Path of Non Performing Loans-A Panel Data Analysis from Mauritian Banks and Implications for the Banking Industry. The Journal of Developing Areas, 49(1), 53-64. https://doi.org/10.1353/jda.2015.0042

Rahman, Md. A., Asaduzzaman, Md., \& Hossin, Md. S. (2016). Impact of Financial Ratios on Non-Performing Loans of Publicly Traded Commercial Banks in Bangladesh. International Journal of Financial Research, 8(1), 181. https://doi.org/10.5430/ijfr.v8n1p181

Rahman, Md. A., Asaduzzaman, Md., \& Hossin, Md. S. (2017). Impact of Financial Ratios on Non-Performing Loans of Publicly Traded Commercial Banks in Bangladesh. International Journal of Financial Research, 8(1), 181. https://doi.org/10.5430/ijfr.v8n1p181

Sari, B., Priyarsono, D., \& Anggraeni, L. (2015). Bank-Specific and Macroeconomic Determinants of Non-Performing Loan of Regional Development Banks in Indonesia. International Journal of Science and Research, 6, 2319-7064. https://doi.org/10.21275/ART2017674

Shingjergji, A., \& Aleksander, ". (2013). The Impact of Bank Specific Variables on the Non Performing Loans Ratio in the Albanian Banking System. In Research Journal of Finance and Accounting www.iiste.org ISSN (Vol. 4, Issue 7). Online. www.iiste.org

Stern, G. H., \& Feldman, R. J. (2004). Too Big To Fail: The Hazards of Bank Bailouts . Brookings Institution Press.

Swamy, V. (2012). Impact of macroeconomic and endogenous factors on non performing bank assets. In The International Journal of Banking and Finance (Vol. 9, Issue 1).

Undang-Undang No. 7 Tahun 1992 tentang Perbankan.

Undang-Undang No. 10 Tahun 1998 tentang Perbankan.

Vatansever, M., \& Hepşen, A. (2013). Determining Impacts on Non-Performing Loan Ratio in Turkey. In Journal of Finance and Investment Analysis (Vol. 2, Issue 4). online) Scienpress Ltd. 
Owner: Riset \& Jurnal Akuntansi

e-ISSN : 2548-9224|p-ISSN : 2548-7507

Volume 6 Nomor 1, Januari 2022

DOI : https://doi.org/10.33395/owner.v6i1.569

Waweru, N. M., \& Kalani, V. M. (2009). Commercial Banking Crises in Kenya: Causes and Remedies. In Global Journal of Finance and Banking Issues (Vol. 3, Issue 3). https://www.researchgate.net/publication/228201353 